\title{
Modeling of Soil Erosion and Its Implication to Forest Management
}

\author{
Nuray Misir and Mehmet Misir \\ Additional information is available at the end of the chapter
}

http://dx.doi.org/10.5772/53741

\section{Introduction}

Conservation of natural forest ecosystems will require a land ethic as prelude to understanding the functioning of forest ecosystems, ecological and physiological impacts of disturbances on ecosystems, and the processes involved in recovery of disturbed ecosystems. Many of the harmful effects of pollution, fire, flooding, and soil compaction can be abated by judicious planning measurements to create and perpetuate the critical components of forest stand structure and species composition. Strategies for continuous production of the products and services that can be supplied by forest ecosystems will need to be reinforced by expanded long-term research and close cooperation among various disciplines such as forest biologists, social scientists, economists, and regulatory government agencies [17].

Nowadays, multi-objective planning is necessary in forestry because of increased and varied demand for forest products and services. Management objective such as production of quality potable water, carbon stocking, aesthetic, recreation and community health in forest especially adjacent to big cities are of great importance. Forests have managed to produce wood products at various diameters and quality classes as the society demanded overtime [24]. Afterwards, the importance of these objectives has gradually diminished and overwhelmed by other management objectives such as conservation of water resources, prevention of soil erosion, carbon stocking, creation of landscape aesthetic, camouflaging military facilities and allocation of land for recreation [2]. The forest values on be grouped as static and dynamic forest values (Figure 1). 


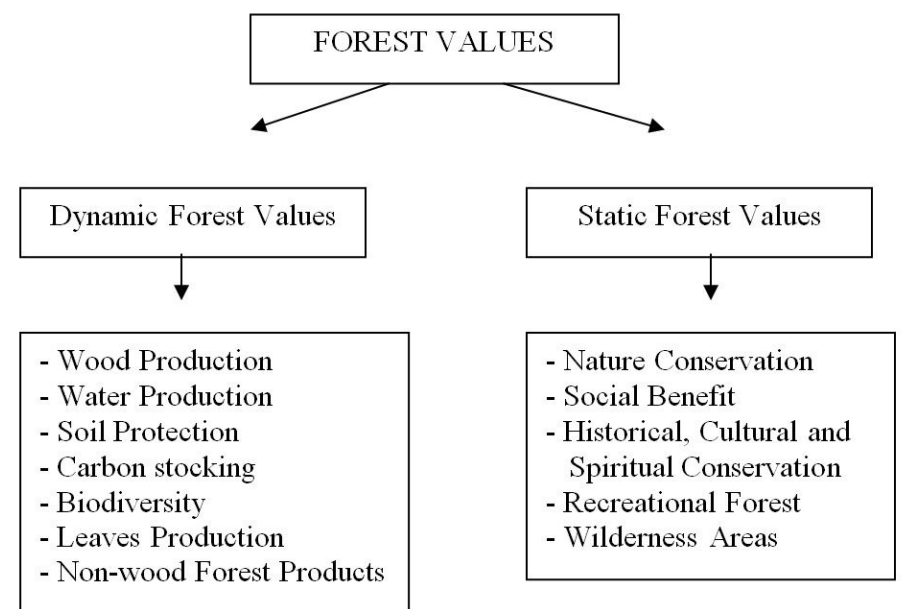

Figure 1. Classification of Forest values [23]

\section{Soil Erosion}

Erosion, the detachment of soil particles, occurs by the action of water, wind, or glacial ice. Such 'background' soil erosion has been occurring for some 450 million years, since the first land plants formed the first soil. Only erosion caused by water will be considered here. Water related erosion occurs when raindrops, spring runoff, or floodwaters wear away and transport soil particles. Erosion is a complex natural process that has often been accelerated by human activities such as land clearance, agriculture, construction, surface mining, and urbanization.

Soil erosion by water and wind affects both agriculture and the natural environment, and is one of the most important of today's environmental problems. It isn't easy to find comprehensive information about erosion, as the subobject is multidisciplinary involving geomorphologists, agricultural engineers, soil scientists, hydrologists and others; and is of interest to policy-makers, farmers, environmentalists and many other groups.

Schumm and Harvey [32] believe some of the terms used to describe erosion are misleading. Normal erosion and geologic erosion are often meant to imply pre-agricultural conditions of low erosion rates, whereas accelerated erosion and historic erosion imply greatly increased erosion rates caused by man. Because of the great variability in natural erosion both spatially and temporally at present and throughout geologic time, neither concept is correct. They prefer the term natural erosion for normal and geologic erosion, and the term man-induced erosion for accelerated and historic erosion. 


\section{Forest Management and Soil Erosion}

All forest management activities affect soils, with effects ranging over a continuum from nearly none where the activity is minimal to large. To foster communication, a threshold should be established above which effects merit attention and below which further consideration is not justified. The magnitude of that threshold varies with the state of knowledge, about forest dynamics and must include recognition of uncertainty. Failure to identify thresholds inhibits communication to a wider audience and even among ourselves [12].

There are two kinds of effects of forest management on soils. The first, direct effect is an alteration of soil properties such as an increase in bulk density following passage of heavy equipment. Soil scientists generally agree on those direct effects; recognition of those alterations is literally axiomatic. The second effect of management on soils is indirect; a change in site productivity due to alteration of soil properties. Some of those secondary effects are obvious enough that can be considered corollaries. Specific studies and personal and vicarious experience have led to this worldview. Conversely, some of the indirect effects of management on soils are not as clear, and can be considered postulates. The distinction between axioms, corollaries, and postulates is often in the eye of the beholder, and depends on interpretation of both published reports and personal observations. Papers that support a position are evaluated differently than those in opposition. I offer no excuses for bias; "For every expert, there is an equal and opposite expert" [6].

Erosion is a natural process, but one whose rate and extent is exacerbated by forest management [36]. Most emphasis on erosion has been directed towards its effects on water quality and fish habitat, but because it involves displacement of soil, the growing medium, erosion also can affect site productivity [21]. However, forest management activities are necessary parts of forestry, and there may be minimal control over the circumstances under which they are carried out. Alterations of soil physical properties are extensive, immediate, and their effects in reducing productivity are well-documented. Chemical and biological properties of soils are also changed by management activities, but the effects on productivity are less well-documented and of longer term; their influence is not clear. Historical evidence shows that forest ecosystems are dynamic and resilient. Assessment of the consequences of changes in properties must recognize that shifts in preferred species should not be equated with changes in productivity, and that short-term effects, measured by the length of most experiments or observations, may not be indicative of long-term effects [12]. Accurate assessment of the effects of its change, however, is likely to continue to be obscured by the influence of the many other elements that also affect forest productivity [40]. At our current state of ignorance, a reasonable approach may be a simple sensitivity analysis that uses spatially based techniques (geographic information systems) and reasonable estimates of effects of the many factors that affect forest productivity to develop an impression of changes in soil productivity [12].

Use of more sophisticated simulation models implies greater knowledge than we currently possess. Both ethical and economic considerations demand good stewardship with professional accountability for our natural resources. Extensive forest management, if carried out 
with both wisdom and prudence, is not antithetical to good stewardship. "All of us have vested interests in making forest management a wise and efficient use of resources. Soil information can immeasurably help us be good stewards of the land" [12].

\section{Soil Loss Characterization}

Characterization of soil loss is very important for environment and natural resources. In erosion control planning, soil loss estimates for a particular site are determined using a prediction model and compared with a T-value for that site [31]. The Universal Soil Loss Equation (USLE) is an example of a model used extensively to predict erosion from croplands and rangelands. More recently, the Agricultural Research Service, Forest Service, and the Bureau of Land Management have joined in a cooperative effort, the Water Erosion Prediction Project (WEPP). WEPP has been implemented to develop an improved model based on modern technology for estimating soil erosion by water. WEPP technology is based on fundamental hydrologic and soil erosion processes and is designed to replace the widely used USLE [8].

Until recently, prediction of soil loss rates on National Forest lands involved using the USLE $[8,22]$. Soil losses were evaluated in the context of potential soil losses, natural soil losses, current soil losses and tolerable soil losses. Potential losses were those that would occur after complete removal of the vegetation and litter. Natural losses were associated with the potential natural vegetation community. Current losses were those occurring with current management. Tolerable loss was assumed to be the rate that can occur while sustaining inherent site productivity [8].

The Universal Soil Loss Equation (USLE) is a widely used method for calculating annual soil losses, based on rainfall, runoff, slope, runoff length, soil type and landuse parameters. The equation originally developed on small agricultural plots, but has been adopted for evaluating erosion from large watersheds under a wide range of land uses. [41]

$$
A=R \times K \times L \times S \times C \times P
$$

where $A$ represents the soil loss, commonly expressed in tonnes ha $^{-1}$ year $^{-1} . R$ refers to the rainfall erosivity factor, calculated by the summation of the erosion index EI30 over the period of evaluation. EI30 is a compound function of the kinetic energy of a storm and its 30min maximum intensity. The latter factor is defined as the greatest average rainfall intensity experiences in any 30-min period during a storm. $K$ is the soil erodibility factor reflecting the susceptibility of a soil type to erosion. It is expressed as the average soil loss per unit of the $\mathrm{R}$ factor. $L$ is an index of slope length, $S$ is a slope gradient index, $C$ is an index for the protective coverage of canopy and organic material in direct contact with the ground. It is measured as the ratio of soil loss from land cropped under specific conditions to the corresponding loss from tilled land under clean-tilled continuous fallow conditions. Finally, the protective factor $\mathrm{P}$ represents the soil conservation operations or other measures that 
control the erosion, such as contour farming, terraces, and strip cropping. It is expressed as the ratio of soil loss with a specific support practice to the corresponding loss with up-anddown slope culture [41].

Soil loss rates have been generally estimated in agricultural areas up to now. Various USLE and GIS combinations have been used to estimate soil loss in forest land [25]. But in this kind of studies, soil loss was determined by quantitatively. For example; in study realized in Taiwan estimating watershed erosion using GIS coupled with the USLE in agricultural areas. Furthermore a WinGrid system was developed to calculate slope length factor (L) in USLE [4].

Samar [30] developed three soil loss prediction models (WEPP, EPIC, ANSWERS) and used them for simulating soil loss and testing their capability in predicting soil losses for three tillage systems (rigde-till, chise-plow, and no-till). In other study (leave a space after point), USLE and GIS combination were used to predict long-term soil erosion and sediment transportation from hillslopes to stream networks under different climate conditions and forest management scenarios. Soil erosion was predicted by the USLE watershed level. The GIS utilities are employed to calculate total mass of sediment moving from each cell to nearest stream network [35]. Misir et al. [25] developed a soil loss model applicable for forest management scenarios for forested areas in northern Turkey.

Forest values including soil protection function need to be determined quantitatively in multi-objective forest management planning. Relationships between soil loss and stand structure on a particular must be determined before incorporation of soil protection values into multi-objective forest management plans.

\section{Soil Loss Estimation}

The soil loss expressed as ton ha ${ }^{-1}$ year-1 is determined using the Universal Soil Loss Equation (USLE). Soil samples are collected from sample plots and analyzed in a laboratory for soil properties including; silt $\%$, sand $\%$, clay $\%$, organic matter $\%$, and classes for structure and permeability. The soil erodibility factor $\mathrm{K}$ values of soil samples are calculated using the following equation [41]:

$$
K=\frac{2.1 \times M^{1.14} \times 10^{-4} \times(12-O M)+3.25 \times(S-2)+2.5 \times(P-3)}{100}
$$

where $O M$ is soil organic matter content, $M$ is (\%silt + \%very fine sand)x(100-\%clay), $S$ is soil structure code and $P$ is permeability class. If soil organic matter content was greater or equal to $4 \%$, OM was considered constant at $4 \%$. Moreover, the influence of rock fragments on soil loss was accounted for by a subsurface component in the soil erodibility $K$ factor [29]. The rainfall erosivity was differently obtained from average annual rainfall erosivity map for countries or locations. 
The slope length factor L, accounts for increases in runoff volume as downslope runoff lengths increase. The slope stepness factor $S$ accounts for increased runoff velocity as slope stepness increases. These factors were obtained from digitized topographic maps of scale 1:25000.

For direct application of the USLE a combined slope length and slope stepness (LS) factor was evaluated for each sample plots as [1]:

$$
L S=l^{0.5} \times\left(0.0138+0.00965 \times S+0.00138 \times S^{2}\right)
$$

where $l$ is runoff length (meter), $S$ is slope (percent).

Crop and management factor is the soil loss from an area with specified cover. $C$ is a function of landuse conditions such as vegetation type, before and after harvesting, crop residues, and crop sequence. Forest management practices create a variety of conditions that influence sheet and rill erosion. The USLE has been used with varying degrees of success to predict these forms of erosion on forest land. Assigning a proper value to cover-management factor (C) in the USLE is a problem, however. An undisturbed, totally covered forest soil usually yields no surface runoff. What erosion does occur on undisturbed forest land comes from stream channels, soil creep, landslide, gullies, and pipes, none of which are evaluated by the USLE. Logging, road building, site preparation, and similar activities that disturb and destroy cover expose the soil to the erosivity of rainfall and runoff [41].

Tree categories of woodland are considered separately:

1. undisturbed forest land,

2. woodland that is grazed, burned, or selectively harvested, and

3. forest lands which have had site preparation treatments for re-establishment after harvest.

Factor $\mathrm{C}$ for undisturbed forest land may be obtained from Table 1 [9].

\begin{tabular}{cc}
\hline $\begin{array}{c}\text { Percent of area covered by canopy of } \\
\text { trees }\end{array}$ & Factor C \\
\hline $100-75$ & $0.0001-0.001$ \\
\hline $70-45$ & $0.002-0.004$ \\
\hline $40-20$ & $0.003-0.009$ \\
\hline
\end{tabular}

Table 1. Factor $C$ for undisturbed forest land

The conservation practice factor $P$, is determined by the extend of conservation practices such as strip, cropping, contouring, and terracing practices, which tend to decrease the erosive capabilities of rainfall and runoff. Values of $P$ range from zero to one. 


\section{Data Analysis and Modeling}

The candidate variables modeling are numerous and diverse. Hartanto et al. [14] classified such variables in four groups: Soil characteristics, physiographic properties, climatic properties and stand characteristics. The candidate variables of soil loss models can be divided in to two groups:

1. measures of physiographic structure and

2. measures of the stand level of structure and density.

Altitude, exposition, aspect, slope and exposure length have been used as measures of physiographic structure. Mean height, mean diameter, crown closure and stand density may have been used as measures of the stand level of structure.

Several possibilities exist to describe stand density. Hamilton [13], Ojansuu et al. [26], Vanclay [38], Thus [37], all of whom used $B A$, and [3], who used $N$, have provided examples of models with stand density parameters as explicatory variables in modeling. Since $N$ and $B A$ were directly determined, and did not rely on functional relationships, as opposed to volume $(V)$, different stand density indexes $[7,28,10,5]$ may be tested.

The soil loss model should be applicable to different stand structures. Therefore, all variables must be tested. Based on the discussion above, the following soil loss models have been generally hypothesized:

$$
\hat{A}=\beta_{0}+\beta_{1} S_{1}+\beta_{2} S_{2}+\beta_{3} S_{3}
$$

where $S_{1}$ is the physiographic structure (altitude, exposition, aspect, slope and exposure length), $S_{2}$ is the stand structure $\left(\bar{d}_{q}, \bar{h}_{q}\right.$ and crown closure) and $S_{3}$ is the stand density.

Relationship between magnitude of soil loss obtained from sample plots and stand characteristics have been used to model soil protection value one of the forest values for quantifying soil loss by using linear, nonlinear, mixed linear and mixed nonlinear procedures in Regression Analysis Method The significance of parameter estimates was tested by means of $t=\mathrm{b} / \mathrm{ASE}$, where $b$ is the parameter estimate and ASE is the asymptotic standard error. The parameters of the model for data have been determined using a software package (e.g. SPPS, SAS). Only were variables which are significant $(P<0.05)$ included in the equation. A soil loss model is constructed based on some site and stand characteristics as a predictor and possible insignificant predictor are excluded. The predicted variable in the soil loss model is annual soil loss amount, which resulted in a linear or nonlinear relationship between the dependent and independent variables. The predictors of a soil loss model were chosen from stand level characteristics as well as their transformations. Some of them had to be significant at the 0.05 level without any systematic errors in residuals. The assumption of homoscedasticity has been tested using the Durbin-Watson test. 


\section{Model Validation}

The soil loss model was evaluated quantitatively by examining the magnitude and distribution of residuals to detect any obvious patterns and systematic discrepancies, and by testing for bias and precision to determine the accuracy at model predictions [39, 33, 11, 20]. Relative bias and root mean square error have been calculated as follows:

$$
\begin{aligned}
\text { Bias } & =\frac{\sum_{i=1}^{n}\left(A_{i}-\hat{A}_{i}\right)}{n} \\
R M S E & =\sqrt{\frac{\sum_{i=1}^{n}\left(A_{i}-\hat{A}_{i}\right)^{2}}{n-p}}
\end{aligned}
$$

where $n$ is the number of observations, $p$ is the number of parameters in the model, $\mathrm{A}_{\mathrm{i}}$ and $A_{i}$ are observed and predicted soil loss values, respectively.

In addition, the models were further validated by an independent control data set. The validation of a model should involve independant data. Data were partitioned in two independent groups, one for model development of soil loss estimation and the other set for validation. The data set used for model development of soil loss eestimation comprised approximately $80 \%$ of the plots, while the remaining $20 \%$ of plots were used for validation. Although the number of sample plots determined for development of soil loss estimation was made relatively large in order to provide sufficient data for model development phase, the number of sample plots in the test data still should be large enough for validation and appropriate statistical test. The deviations between predicted and observed values were tested by Student's Paired-t test or Wilcoxon test.

\section{Sample size}

The size of sample plot for sampling can be an advantage or disadvantage to model soil loss. A plot size of $800 \mathrm{~m}^{2}$ means that a relatively large number of the trees are not affected by the forest conditions outside the plot. In other words, a relatively number of trees is affected by the forest conditions inside the plot. In this kind of studies plots that might have been subjected to any harvesting operation between the measurements were excluded from the data material because of insufficient information about treatments. If the harvest on these plots was a result of "regular" management practices, there were no problems related to the exclusion [37]. However, if the harvest was a result of an extraordinary situation (i.e. floods), exclusion of the plots may have lead to an underestimated soil loss amount. 


\section{Uncertainty}

There are many sources of uncertainties related to large scale forestry analyses in general, e.g. related to the inventory of input variables used as basis for the analyses [e.g. 16], to model errors of the numerous functions used for predictions [e.g. 15], to the stochasticity of future condition [e.g. 18, 27] and to the stochasticity of future prices and costs [e.g. 34, 19]. Thus [37], as long as the soil loss models are unbiased, they will not introduce any substantial change with respect to the final uncertainty of large scale forestry analyses.

\section{Conclusions}

Soil loss is an important variable which is used for multiple forest management planning.

Measuring soil loss is costly; however, foresters usually welcome an opportunity to estimate this function (forest value) with an acceptable accuracy. Missing soil losses may be estimated using a suitable soil loss equation. Based on a comprehensive data set which includes very different stands, such soil loss equation should be fitted for a major tree species in complex.

The stand position and stand density measures used in this kind of studies and variables entered to the soil loss model are easily obtained and are available in forest inventories. In summary, the suggested or developed soil loss models improve the accuracy of soil loss prediction, ensure compatibility among the various estimates in a forest management scenario, and maintain projections with reasonable biological limits.

Linear, nonlinear or mixed models for prediction of soil loss for stand level, designed for use in large scale forestry scenario models and analyses, may been developed. Although soil loss as a phenomenon is complicated to model, and in spite of several uncertain topics revealed from the work, the model fit and the validation tests may be turned out satisfactory.

Provided the many uncertainties of large scale forestry scenario analyses in general, soil loss models seem to hold an appropriate level of reliability, and we feel that it can be applied in such analyses. This does not mean that the model cannot be enhanced, however. With new rotations of permanent sample plots measurements, the models should be evaluated and, if necessary, revised or calibrated.

\section{Author details}

Nuray Misir ${ }^{1 *}$ and Mehmet Misir ${ }^{2}$

*Address all correspondence to: nuray@ktu.edu.tr

1 Karadeniz Technical University, Faculty of Forestry, Turkey 
2 Department of Forest Management, Turkey

\section{References}

[1] Arnoldus, H. M. J. (1977). Predicting soil losses due to sheet and rill erosion. FAO conservation guide no.1, Guidelines for watershed management, Rome, Italy.

[2] Asan, Ü. (1992). letme sınıfı ayrımında fonksiyonel yaklaşım. Orman Mühendisliği Dergisi, 5, 30-31.

[3] Burgman, M., Incoll, W., Ades, P., Ferguson, I., Fletcher, T., \& Wholers, A. (1994). Mortality models for mountain and Alpine Ash. Forest Ecology and Management, 67, 319-327.

[4] Chao-Yuan, L., Wen-Tzu, L., \& Wen-Chieh, C. (2002). Soil erosion prediction and sediment yield estimation: the Taiwan experience. Soil \& Tillage Research, 68, 143-152.

[5] Chisman, H. H., \& Schumacher, A. F. (1940). On the tree-area ratio and certain of its applications. Journal of Forestry, 38, 311-317.

[6] Clarke, A. C. (1998). President, Experts and Asteroids. Science, June, 5, 1532-1533.

[7] Curtis, R. O., Clendenan, G. W., \& Demars, D. J. (1981). A new stand simulator for coast douglas-fir: DFSIM users guide: U.S. forest service general technical report PNW-128.

[8] De Bano, L. F., \& Wood, M. K. (1990). Soil loss tolerance as related to rangeland productivity. Proceedings of the Soil Quality Standards Symposium. U.S. Department of Agriculture, Forest, Service Publication WO-WSA-2. , 15-27.

[9] Dismeyer, G. E., \& Foster, G. R. (1984). Estimating the cover-management factor (C) in the Universal Soil Loss Equation for forest conditions. Journal of Soil and Water Conservation, 36, 235-240.

[10] Drew, T. J., \& Flewelling, J. W. (1977). Stand density management: an alternative approach and its application to Douglas-Fir plantations. Forest Science, 25, 518-532.

[11] Gadow, K., \& Hui, G. (1998). Modelling forest development. Faculty of forest and woodland ecology, University of Göttingen.

[12] Grigal, D. F. (2000). Effects of Extensive Forest Management on Soil Productivity. Forest Ecology and Management, 138(1-3), 167-185.

[13] Hamilton, D. A. (1986). A Logistic model of mortality in thinned and unthinned mixed conifer stands of Northern Idaho. Forest Science, 32, 989-1000.

[14] Hartanto, H., Prabhu, R., Widayat, A. S. E., \& Adsak, C. (2003). Factors affecting runoff and soil erosion: Plot-level soil loss monitoring for assessing sustainability of forest management. Forest Ecology and Management, 141, 1-14. 
[15] Kangas, A. (1996). On the bias and variance in tree volume predictions due to model and measurement errors. Scandinavian Journal of Forest Research, 11, 281-290.

[16] Kangas, A., \& Kangas, J. (1999). Optimization bias in forest management planning solutions due to errors in forest variables. Silva Fennica, 33, 303-315.

[17] Kozlowski, T. T. (2000). Responses of woody plants to human-induced environmental stresses: Issues, problems, and strategies for alleviating stress. Critical Reviews in Plant Sciences, 19(2), 91-170.

[18] Larsson, M. . (1994). The significance of data quality in compartmental forest registers in estimating growth and non-optimal losses-a study of final felling Compartments in Northern Sweden. Report 26. Swedish University of Agricultural Sciences Umea, Sweden

[19] Leskinen, P., \& Kangas, J. (1998). Analysing uncertainties of interval judgment data in multiple criteria evaluation of forest plans. Silva Fennica, 32, 363-372.

[20] Mabvurira, D., \& Miina, J. (2002). Individual-tree growth and mortality models for Eucalyptus grandis (Hill) maiden plantations in Zimbabwe. Forest Ecology and Management, 161(1-3), 231-245.

[21] Megahan, W. F. (1990). Erosion and site productivity in Western-Montane forestecosystems. Symposium on Management and Productivity of Western-Montane. Boise, ID, USDA Forest Service General Technical Report INT-280, 146-150.

[22] Megahan, W. F. (1992). Logging erosion sedimentation... Are they dirty words? Journal of Forestry, 70(7), 403-407.

[23] Misır, M. (2001). Developing a Multi objective model forest management plan using GIS and Goal Programming (A case study of Ormanüstü Planning Unit). Karadeniz Technical University, PhD Thesis, Trabzon.

[24] Misır, M., \& Başkent, E. Z. (2002). The role of GIS in Multi objective forest planning. International Symposium on GIS, İstanbul, Tukey, Proceedings, 449-465.

[25] Misır, N., Misır, M., Karahalil, U., \& Yavuz, H. (2007). Characterization of soil erosion and its implication to forest management. Journal of Environmental Biology, 28(2), 185-191.

[26] Ojansuu, R., Hynynene, J. , Koivunen, J., \& Luoma, P. Luonnonprosessit metsalaskelmassa. 1991, METSA 2000, 385, 1-59.

[27] Pasanen, K. (1998). Integrating variation in tree growth in to Forest Planning. Silva Fennica, 32, 11-25.

[28] Reineke, L. H. (1933). Perfecting a stand density index for even-aged forests. Journal of Agricultural Research, 46(7), 627-638.

[29] Renard, K. G., Foster, G. R., Weesies, G. A., Mc Cool, D. K., \& Yoder, D. C. (1997). Predicting soil erosion by water: A guide to conservation planning with the Revised 
Universal Soil Loss Equation (RUSLE). USDA Agricultural Research Service Handbook [703].

[30] Samar, J., Bhuyan, Prasanta. K., Kalita, Keith. , \& Janssen, A. (2002). Soil loss predictions with three erosion simulation models. Environmental Modeling, 17(2), 137-146.

[31] Schmidt, B. L., Allmaras, R. R., \& Mannering, J. V. (1982). Preface in: Determinants of soil loss tolerance. ASA Special Publication,No. 45, Am. Soc. Agr., Madison, Wiscon.

[32] Schumm, S. A., \& Harvey, M. D. (1982). Natural Erosion in USA. Schmidt, B.L., ed. Determinants of Soil Loss Tolerance. Madison, WI: American Society of Agronomy, Special Publication, 45, 23-29.

[33] Soares, P., Tomé, M., Skovsgaard, J. P., \& Vanclay, J. K. (1995). Evaluating a growth model for forest management using continuous forest inventory data. Forest Ecology and Management, 71, 251-265.

[34] Stähl, G. (1994). Optimal stand level inventory intensities under deterministic and stochastic stumpage value assumptions. Scandinavian Journal of Forest Research, 9, 405-412.

[35] Sun, G., \& Mc Nulty, S. D. (1998). Modeling soil erosion and transport on forest landscape. Conference 29, NV. Steamboat Springs, Co: International Erosion Control Association, 187-198.

[36] Swanson, F. J., Clayton, J. L., Megahan, W. F., \& Bush, G. (1989). Erosional processes and long-term site productivity. Perry, D. A., Meurisse, R.; Thomas, B., Miller, R., Boyle, J., Means, J., Perry, C. R., Powers, R. F., eds. Maintaining The Long-Term Productivity of Pacific Northwest Forest Ecosystems. Portland, OR: Timber Press, 67-81.

[37] Thus, E. (1997). Naturlig avgang av traer (Natural mortality of trees). Raport Fra Skogfrosk, 6.

[38] Vanclay, J. K. (1991). Mortality functions for North Queensland rain forests. Journal of Tropical Forest Science, 4(1), 15-36.

[39] Vanclay, J. K. (1994). Modelling forest growth and yield, applications to mixed tropical forests,. CAB International, Wallingford, UK.

[40] Weetman, G. F. (1998). A forest management perspective on sustained site productivity. Forestry Chronical, 74, 75-77.

[41] Wischmeier, W. H., \& Smith, D. D. (1978). Predicting rainfall erosion losses-a guide to conservation planning. USDA agricultural research service handbook, no. 537, Washington, D.C. 